Bayero Journal of Pure and Applied Sciences, 6(1): 46 - 51

Received: December 2012

Accepted: May 2013

ISSN $2006-6996$

\title{
EVALUATION OF CRITICAL CONTROL POINTS (CCPS) IN THE PRODUCTION OF 'DADDAWA' (AFRICAN LOCUST BEAN CAKE) IN DAWAKIN - TOFA LOCAL GOVERNMENT AREA, KANO STATE, NIGERIA
}

\author{
${ }^{1}$ Rabi, M., ${ }^{2}$ Mukhtar, M.D., ${ }^{2}$ Kawo, A.H., ${ }^{2}$ Shamsuddeen, U. and ${ }^{2}$ Bukar, A.* \\ ${ }^{1}$ Department of Science Laboratory Technology, School of Technology, P.M.B 3401, Kano State, Nigeria \\ ${ }^{2}$ Department of Microbiology, Bayero University, PMB 3011, Kano State, Nigeria. \\ *Correspondence author: al_amsak2004@yahoo.com, 2348023567064
}

\begin{abstract}
Hazard analysis and critical control point (HACCP) was carried out during the production of African locust bean seeds condiment (Daddawa) in a location that specialized in it's manufacturing namely Kwanar - yandaddawa (Dawakin - Tofa Local Government Area) Kano State, Nigeria. The analyses consisted of determination of the aerobic, anaerobic mesophilic bacterial, staphylococcal and fungal counts. In addition, detection of $\mathrm{E}$. coli 0157: $\mathrm{H}$, Staphylococcus aureus and Clostridium perfringens on the raw seeds before processing and the processed daddawa were also carried out. The raw seeds, processed seeds, production stages and additives had high total microbial count in the range of $10^{9}-10^{11} \mathrm{cfu} / \mathrm{g}$, which is above the maximum acceptable limit of $10^{5} \mathrm{cfu} / \mathrm{g}$. Bacteria isolated and biochemically characterized were Staphylococcus spp, Clostridium perfringens and $E$. coli 0157: H7. Mucor and Rhizopus were the fungal genera frequently isolated from most of the samples with Aspergillus fumigatus least isolated. Clostridium botulinum was not isolated at Kwanar yandaddawa. The raw seeds, sand used in dehauling, diluents, pawpaw leaves used as additives as well as final molding, comparing (tabletting) and display for sale to consumers are therefore regarded as a critical control points.
\end{abstract}

Keywords: Aerobes, anaerobes, E. coli 0157: H7, Critical Control Points.

\section{INTRODUCTION}

Hazard Analysis Critical Control Point (HACCP) is a systematic preventive approach to food safety that addresses physical, chemical and biological hazards as means of prevention rather than finished product inspection. HACCP is used in the food industry to identify potential food safety hazards, so that key actions can be taken to reduce or eliminate the risk (International Commission on Microbiological Specifications for Foods, ICMSF, 1988).

HACCP is a management system in which food safety is addressed through the analysis of physical, chemical and biological hazards from raw materials, processing, procurement, handling, to manufacturing, distribution and consumption of the finished products (National Advisory Committee on Microbiological Criteria for Foods, NACMCF, 1997). The microbiological safety of the fermented foods can be improved upon greatly by using quality raw materials using unique starter cultures that have the ability to detoxify, maintaining proper hygienic standards in the processing environment and using proper packaging as reported by Ijabadeniyi and Omoya (2006).

Locust beans condiment (Daddawa - 'Hausa', Iru - 'Yoruba', Ogiri - 'Igbo') was observed to be a delicacy used as food seasoning, flavour enhancer and aroma that was found to be produced at commercial scale in a locality in Kano State. Food and microorganisms have an interesting association that was developed long before the beginning of recorded history. Fermented food condiments are good source of nutrient and could be used to produce complementary food supplements (Achi, 1999). Daddawa is a condiment which added aroma and flavor to dishes such as Jallof rice, baobab soup ("Miyar kuka"), fish pepper soup, and chicken pepper soup (Yakubu, 2009). Yet there is a popular claim by consumers that the product is always contaminated by microorganisms at each stage of the production process and also during transportation and marketing. The paper was aimed at evaluating the possible critical control points during the production of Daddawa at Dawakin - Tofa Local Government area of Kano state with a view to highlight ways of reducing sources of potential hazards during the production of daddawa.

\section{MATERIALS AND METHODS}

\section{Sampling site}

The samples were collected from Kwanar yan Daddawa, an area in Dawakin Tofa Local Government Area of Kano State, popular for the production of Daddawa.

\section{Sample collection}

Various samples were collected from the production stages of daddawa, which were coded, namely, B1 (Raw seeds), B2 (Fermented seeds), B3 (Sand), B (Washed seeds with testa), $B_{5}$ (Hibiscus sabdariffa), $B_{6}$ (Fermented seeds), $B_{7}$ (Hand swab), $B_{8}$ (Pestle), $B_{9}$ (Mortar), $B_{10}$ (Floor swab), $B_{11}$ (Dryer), $B_{12}$ (Diluent), $B_{13}$ (Ash), $B_{14}$ (Basket swab), $B_{15}$ (pawpaw leaves), $B_{16}$ (Sack). All the samples were collected according to the method of the Food and Agricultural Organization (FAO, 1979). 


\section{Microbiological Analyses of daddawa}

\section{Enumeration of microorganisms}

Aerobic and anaerobic bacterial count, Staphylococcal count and fungal count were enumerated according to the procedure described by FAO (1979) and Cheesebrough (2000).

\section{Isolation and characterization of some pathogens}

E. coli 0157: H7, C. perfringens, C. botulinum and some fungal genera were isolated and characterized according to the procedure described by FAO (1979) and Cheesebrough (2005).

\section{Determination of Critical Control Point}

The result obtained from the microbiological analyses of each step was compared with the CCP decision tree (National Advisory Committee on Microbiological Criteria for Foods, NACMCF, 1997), to establish whether the step is a critical control point or not.

Figure 1 show the CCP decision tree.

Does the step involve a hazard of sufficient likelihood of occurrence and severity to warrant it's control?
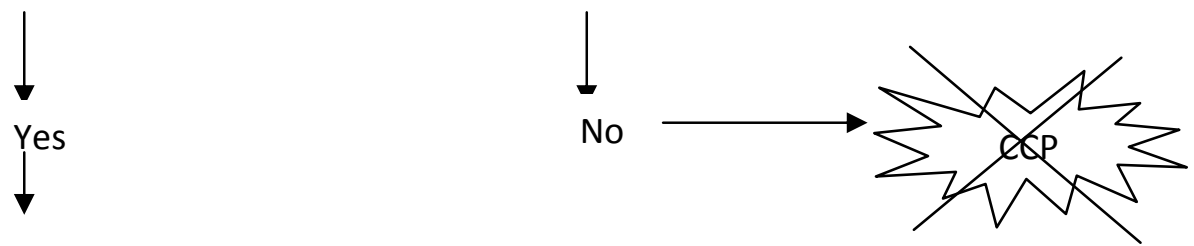

Does a control measure for the hazards exist at this step

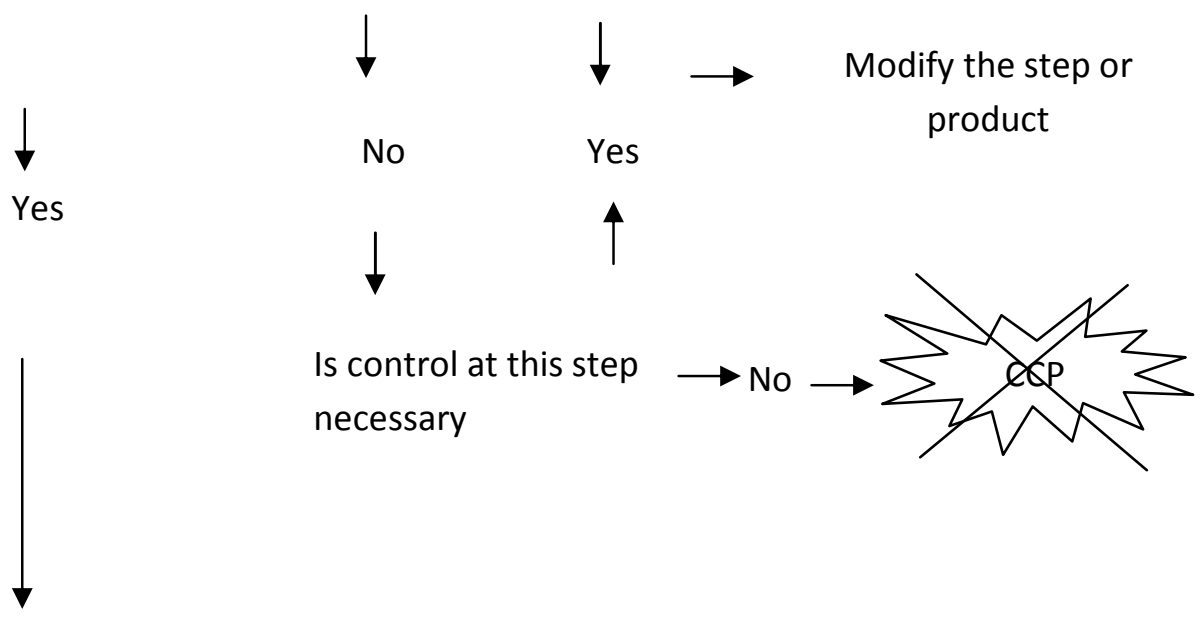

Is control at this step necessary to prevent, eliminate reduce the risk of the hazard to consumers
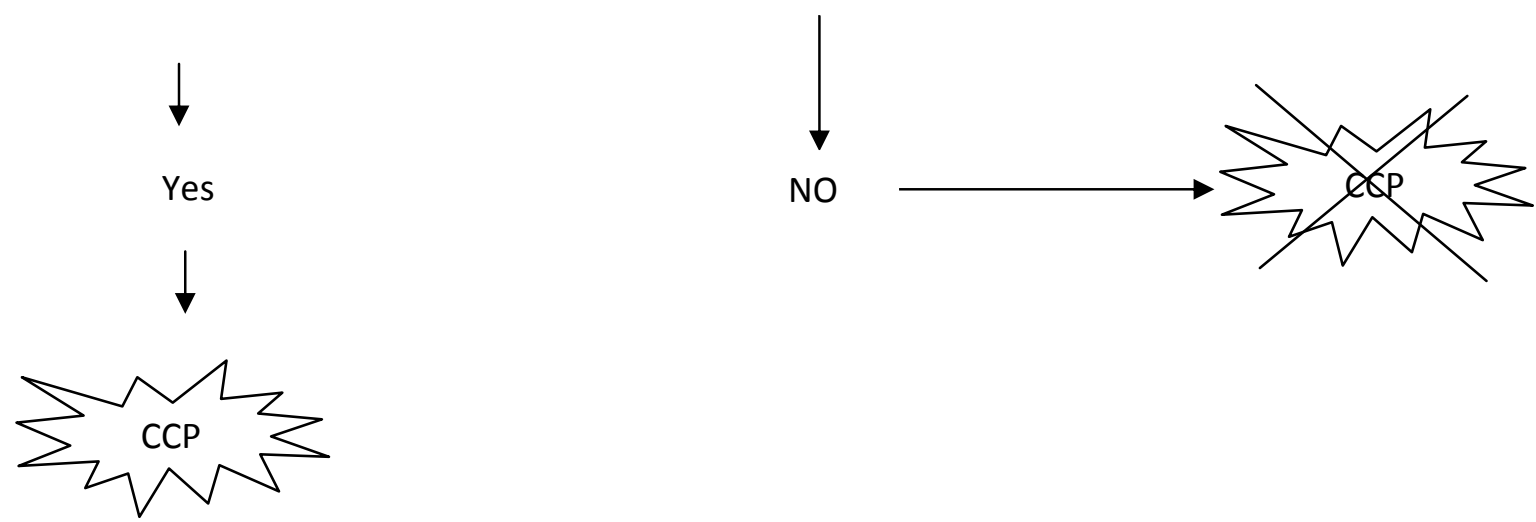

Figure 1: Critical Control Point Decision Tree Source: NACMCF (1997) 


\section{RESULTS AND DISCUSSION}

The mean mesophilic aerobic, anaerobic bacterial and Staphylococcal counts of all the samples in the production stages at the sampling site ranged between $10^{6}$ to $10^{11} \mathrm{cfu} / \mathrm{g}$ (Table 1 ). Compared with FAO (1979) acceptable limit of $10^{5} \mathrm{cfu} / \mathrm{g}$, the products were contaminated with high microbial counts, which could predispose the product to spoilage and also predispose consumers to food - borne illnesses (Bukar et al., 2010). The high microbial counts recovered on the raw materials, production stages and additives could be attributed to the filthy environment where the production take place and also ignorance of the producers on environmental and personal hygiene measures as means of reducing the contamination (Shamsuddeen and Ameh, 2008).

It is beyond reasonable doubt that fermentative products are hardly devoid of microorganisms except if they passed through tyndallization as expatiated by Mackie and McCartney (1989). Raw daddawa was found to have high microbial count based on FAO (1979) acceptable limit. Eventhough daddawa is mostly added to soups and boiled together, thereby killing most or all the microorganisms including the pathogens. In Hausa communities, raw daddawa is grinded together with some other condiments and licked by small children. These children might be exposed to high microbial load of pathogenic bacteria, which might lead to foodborne infections and/or intoxications. In some cases, daddawa is also added to other condiments raw e.g. condiments used in eating grilled/fried meat popularly called Suya in Nigeria. Condiments prepared with raw daddawa could pose hazard to consumers in view of the fact that results of this research have shown the daddawa to have microbial load higher than the maximum acceptable limit of $10^{5} \mathrm{cfu} / \mathrm{g}$, set by the FAO (1979) and NACMCF (1997). Products that have microbial load higher than the maximum acceptable limit or which a pathogen is recovered from the sample should be removed from the market in order to safeguard the health of consumers of such product.

With the exception of Clostridium botulinum, which was not recovered from any of the samples, other pathogens such as $E$. coli $0157: \mathrm{H7}, C$. perfringens and $S$. aureus were recovered from most of the production stages (Table 2), which clearly showed the potential hazard faced by consumers when the daddawa is consumed. E. coli $0157: \mathrm{H7}$, C. perfringens and $S$. aureus are all toxigenic pathogens capable of producing toxins in foods, which when consumed could result in unpleasant conditions (Hocking, 2003).

Fungi such as Mucor and Rhizopus are food spoilers capable of spoiling daddawa, especially when there is little moisture to support their growth (Nester et al., 2004). A. fumigatus was also recovered from the raw seeds (Table 2 ). If it is not removed during the production, it may contaminate the final product and when conditions of temperature and humidity are desirable (Schlegel, 2002), it could produce toxins that could be hazardous to consumers of condiments containing unprocessed daddawa.

Based on the critical control point decision tree (NACMCF, 1997), a step is considered as a critical control point if it involves a hazard of sufficiently likelihood of occurrence and severity to warrant its control, and the control measure exists and the control is necessary in order to eliminate or reduce the hazard to an acceptable level. Therefore, based on the CCP decision tree (NACMCF, 1997), the stages that were supposed to be controlled are the raw material itself, dehauling with sand, addition of Ash, fermentation, sun-drying on floor, addition of pawpaw leaves (that are known to yield tenderizing enzymes) moulding with diluent, sun-drying on mat or cornstalk and display for sale are CCP since there were high bacterial count ranging between $10^{6}$ to $10^{11}$ at Kwanar yandaddawa which were of course higher than acceptable limit $\left(10^{5} \mathrm{cfu} / \mathrm{g}\right)$ provided by the Food and Agriculture Organization (FAO, 1979) of the United Nations. From this work it was clearly observed that, the initial point of contamination of the raw seeds and the finished products was the environment and the handling processes where the seeds and the finished products re not handled hygienically this is in agreement with the work of Shamsudeen and Ameh (2008). Putting the fermented seeds on the floor, which is not clean, as well as mixing it with the additives (diluents, pawpaw leaves, ash and $H$. sabadariffa) as well as dehulling with sand are all suggestive of the unhygienic conditions of the processing practices and the environment. All these could have contributed to the high bacterial populations on the raw seeds as well as the processed products (Daddawa) obtained in this study. This is in line with the report of Shamsuddeen and Ameh (2008). The Microbiological safety of the fermented foods examined can be improved upon greatly by using quality raw materials, maintaining proper hygienic standards in the processing environment and using proper packaging (Ijabadeniyi and Omoya, 2006b).

To eliminate hazards in the various production stages, all the raw materials including additives should be sanitized (Bukar and Magashi, 2008) to eliminate or reduce appreciably the counts of potential spoilage causing and pathogenic microorganisms so as to produce a product free from microbial contamination.

The problem of small - scale food producers in Nigeria is the fact that relevant government agencies such as National Food and Drug Administration and Control (NAFDAC), Standard Organization of Nigeria (SON) etc are not doing enough to reach them and enlighten them on Good Manufacturing Practices (GMP). In fact most of them do not know what GMP means. 
Table 1: Mean bacterial and fungal counts (cfu/g) of samples from the production stages of 'daddawa' at Kwanar yandaddawa

\begin{tabular}{llllll}
\hline $\mathbf{S} / \mathbf{N}$ & Production Stages & $\begin{array}{l}\text { Aerobic } \\
\text { bacteria } \\
\text { count }\end{array}$ & $\begin{array}{l}\text { Anaerobic } \\
\text { bacteria } \\
\text { count }\end{array}$ & $\begin{array}{l}\text { Staphylococcal } \\
\text { count }\end{array}$ & $\begin{array}{l}\text { Fungal } \\
\text { count }\end{array}$ \\
\hline 1 & $\mathrm{~B}_{1}$ (raw seeds) & $4.55 \times 10^{9}$ & $3.20 \times 10^{9}$ & $1.92 \times 10^{8}$ & $4.00 \times 10^{8}$ \\
2 & $\mathrm{~B}_{2}$ (1) boiled seeds) & $5.30 \times 10^{5}$ & $3.40 \times 10^{7}$ & $2.10 \times 10^{6}$ & $3.80 \times 10^{5}$ \\
3 & $\mathrm{~B}_{3}$ (Sand) & $4.05 \times 10^{9}$ & $3.35 \times 10^{9}$ & $8.40 \times 10^{8}$ & $4.00 \times 10^{7}$ \\
4 & $\mathrm{~B}_{4}$ (washed seeds with & $2.26 \times 10^{10}$ & $1.04 \times 10^{9}$ & $7.75 \times 10^{6}$ & $4.80 \times 10^{7}$ \\
& testa) & & & & \\
5 & $\mathrm{~B}_{5}$ (addition of Hibiscus & $4.50 \times 10^{7}$ & $7.55 \times 10^{7}$ & $1.39 \times 10^{9}$ & $8.75 \times 10^{6}$ \\
6 & sabdariffa) $_{6}$ (fermented seeds) & $4.15 \times 10^{9}$ & $4.80 \times 10^{9}$ & $4.50 \times 10^{9}$ & $4.40 \times 10^{8}$ \\
7 & $\mathrm{~B}_{7}$ (hand swab) & $3.00 \times 10^{8}$ & $4.80 \times 10^{8}$ & $4.55 \times 10^{8}$ & $3.45 \times 10^{8}$ \\
8 & $\mathrm{~B}_{8}$ (pestle) & $4.00 \times 10^{8}$ & $3.65 \times 10^{7}$ & $1.52 \times 10^{8}$ & $3.56 \times 10^{8}$ \\
9 & $\mathrm{~B}_{9}$ (mortar) & $3.00 \times 10^{9}$ & $3.40 \times 10^{9}$ & $1.22 \times 10^{9}$ & $4.10 \times 10^{8}$ \\
10 & $\mathrm{~B}_{10}$ (floor swab) & $3.40 \times 10^{9}$ & $3.75 \times 10^{9}$ & $4.00 \times 10^{8}$ & $3.35 \times 10^{9}$ \\
11 & $\mathrm{~B}_{11}$ (dryer) & $4.05 \times 10^{8}$ & $4.75 \times 10^{9}$ & $3.90 \times 10^{7}$ & $3.15 \times 10^{8}$ \\
12 & $\mathrm{~B}_{12}$ (diluent) & $3.25 \times 10^{7}$ & $1.21 \times 10^{8}$ & $3.60 \times 10^{8}$ & $1.21 \times 10^{7}$ \\
13 & $\mathrm{~B}_{13}$ (ash) & $3.00 \times 10^{9}$ & $6.20 \times 10^{6}$ & $6.40 \times 10^{6}$ & $6.20 \times 10^{6}$ \\
14 & $\mathrm{~B}_{14}$ (basket swab) & $3.60 \times 10^{7}$ & $4.40 \times 10^{9}$ & $4.00 \times 10^{7}$ & $1.05 \times 10^{9}$ \\
15 & $\mathrm{~B}_{15}$ (addition of pawpaw & $1.56 \times 10^{7}$ & $1.29 \times 10^{7}$ & $1.24 \times 10^{6}$ & $8.20 \times 10^{5}$ \\
16 & leaves) & & & & \\
& $\mathrm{B}_{16}$ (sack) & $1.97 \times 10^{8}$ & $3.80 \times 10^{8}$ & $1.78 \times 10^{7}$ & $4.80 \times 10^{8}$ \\
\hline
\end{tabular}

FAO (1979) maximum acceptable limit is $1.00 \times 10^{5} \mathrm{cfu} / \mathrm{gm} / \mathrm{ml}$

Table 2: Detection of $E$. coli 0157: H7, C. perfringens, $C$. botulinum and fungal species at the production stages of 'daddawa' at Kwanar yandaddawa.

\begin{tabular}{|c|c|c|c|c|c|c|}
\hline $\mathbf{S} / \mathbf{N}$ & $\begin{array}{l}\text { Production } \\
\text { Stages }\end{array}$ & $\begin{array}{l}\text { E. coli } \\
\text { 0157:H7 }\end{array}$ & $\begin{array}{l}\text { C. } \\
\text { perfringens }\end{array}$ & $\begin{array}{l}\text { Clostridium } \\
\text { botulinum }\end{array}$ & $\begin{array}{l}\text { Staphyloccus } \\
\text { aureus }\end{array}$ & $\begin{array}{l}\text { Fungal } \\
\text { isolated }\end{array}$ \\
\hline 1 & $B_{1}$ (raw seeds) & + & + & - & + & $\begin{array}{l}\text { A. fumigatus, Mucor, } \\
\text { Rhizophus }\end{array}$ \\
\hline 2 & $\begin{array}{l}\mathrm{B}_{2} \quad\left(1^{\text {st }} \text { boiled }\right. \\
\text { seeds })\end{array}$ & - & + & - & + & Mucor, Rhizophus \\
\hline 3 & $\mathrm{~B}_{3}$ (Sand) & - & + & - & + & Mucor, Rhizophus \\
\hline 4 & $\begin{array}{l}\mathrm{B}_{4} \text { (washed seeds } \\
\text { with testa) }\end{array}$ & - & - & - & - & Mucor, Rhizophus \\
\hline 5 & $\begin{array}{l}\mathrm{B}_{5} \text { (addition of } \\
\text { Hibiscus } \\
\text { sabdariffa) }\end{array}$ & - & + & - & + & Rhizopus \\
\hline 6 & $\begin{array}{l}\mathrm{B}_{6} \quad \text { (fermented } \\
\text { seeds) }\end{array}$ & + & - & - & + & Mucor, Rhizophus \\
\hline 7 & $B_{7}$ (hand swab) & + & - & - & + & Mucor, Rhizophus \\
\hline 8 & $\mathrm{~B}_{8}$ (pestle) & - & - & - & + & Mucor, Rhizophus \\
\hline 9 & $\mathrm{~B}_{9}$ (mortar) & - & - & - & + & Mucor, Rhizophus \\
\hline 10 & $\mathrm{~B}_{10}$ (floor swab) & + & + & - & + & Mucor, -Rhizophus \\
\hline 11 & $\mathrm{~B}_{11}$ (dryer) & + & + & - & + & Mucor, Rhizophus \\
\hline 12 & $\mathrm{~B}_{12}$ (diluent) & + & + & - & + & Mucor, Rhizophus \\
\hline 13 & $\mathrm{~B}_{13}$ (ash) & + & + & - & + & - \\
\hline 14 & $\begin{array}{l}\mathrm{B}_{14} \quad \text { (basket } \\
\text { swab) }\end{array}$ & + & + & - & + & Mucor, Rhizophus \\
\hline 15 & $\begin{array}{l}\mathrm{B}_{15} \text { (addition of } \\
\text { pawpaw leaves) }\end{array}$ & - & - & - & + & Mucor, Rhizophus \\
\hline 16 & $\mathrm{~B}_{16}$ (sack) & - & - & - & + & Mucor, Rhizophus \\
\hline
\end{tabular}


Bajopas Volume 6 Number 1 June, 2013

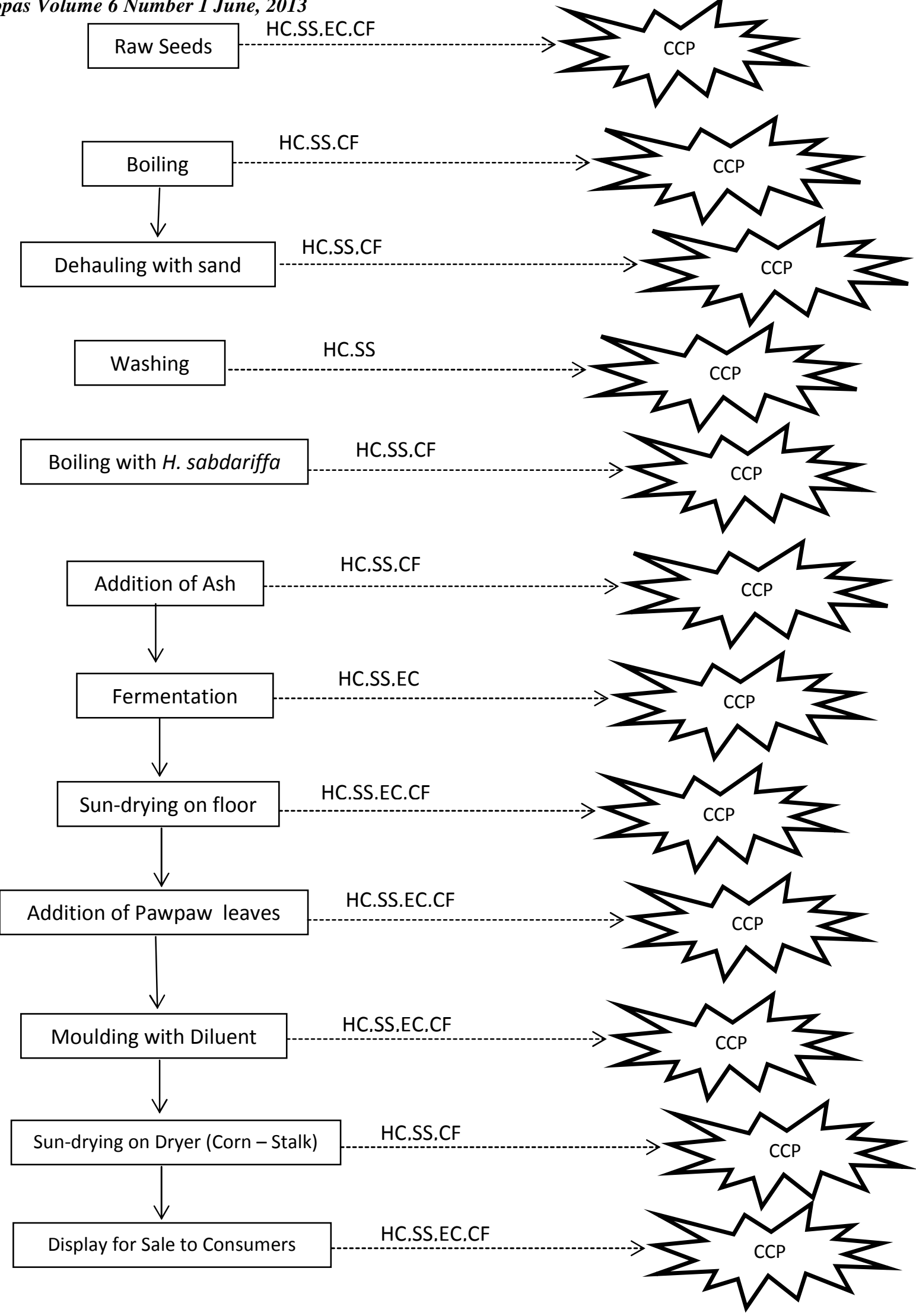

Figure 2: Critical control points from production stages of daddawa at Kwanar yandaddawa

Key: $\mathrm{CCP}=$ Critical control point, $\mathrm{HC}=$ High counts, $\mathrm{SS}=\mathrm{Staph} \mathrm{spp}, \mathrm{EC}=E$. coli, $\mathrm{CF}=$ Clostridium perfringens 


\section{CONCLUSION}

The results of this research have shown that production stages in making daddawa at Kwanar yan daddawa, Dawakin Tofa Local Government, Kano State during the research period are all critical control points capable of contaminating the final daddawa, which could predispose the consumers of the product to food - borne illnesses.

\section{RECOMMENDATIONS}

- More research should be done on the use of novel techniques like nanotechnology and irradiation to ensure Daddawa safety. Dust and flies should be

\section{REFERENCES}

Achi, O.K. (1999). Quality attributes of fermented yam flour supplemented with processed soy flour plant foods Human Nutrition 54: $151-158$.

Bukar, A. and Magashi, A. M. (2008): Preliminary Investigation on the use of Plant Aqueous Extracts as Antimicrobial Washing Solutions on Tomatoes, Peppers and Oranges. International Journal of Pure and Applied Sciences, 2(1):22-26. www.ijpas.com

Cheesbrough, M. (2005): District Laboratory Practice for Tropical Countries, part 2. Cambridge University Press, UK. Pp.180-197.

Food and Agricultural Organization (1979): Manuals of Food Quality Control. 4. FAO Food and Nutrition Paper, United Nations, Rome, 14(4):A1 - F10.

Hocking, A.D (ed.) (2003). Food-borne Microorganisms of Public Health Significance ( $6^{\text {th }}$ edition). Waterloo: Australian Institute of Food Science and Technology.

Ijabadeniyi A.O. and Omoya F.O (2008). Safety of Small - Scale Food Fermentations in Developing Countries. IUFOST $13^{\text {th }}$ World Conference of Food Science and Technology, "Food is life," Nantes France, $17-21$ September, Pp 1833 - 1845. Apt.info/index.php/ajb/article/view58164/465 27. Retrieved on $19^{\text {th }}$ July, 2010. denied access to Daddawa during holding before and after molding.

- It is also recommended that daddawa handlers and operators at Kwanar yandaddawa should exercise personal and environmental hygiene, so as to eliminate any possible hazard or reduce it to an acceptable level.

- The Government and NGO's should financially assist these small-scale industries as well as educating them on Good Manufacturing Practices and personal hygiene. Government and individuals should help in planting more $P$. biglobosa trees to boost the availability of the raw materials to this economically viable industrial manufacturing venture.

International Commission on Microbiological Specification for Foods, ICMSF (1988): HACCP in microbiological safety and quality. Oxford Mead, Blackwell Scientific Publications.

Mackie and McCartney (1989). Practical Medical Microbiology. Churchill Livingstone, Edinburgh London Melbourne and New York. Pp $67-68$.

National Advisory Committee on Microbiological Criteria for Foods (NACMF, 1997). Hazard Analysis and Critical Control Point, Principle and Guidelines.

Nester, E.W., Anderson, D.G., Roberts, C.E.P. and Nester, N.T. (2004): Microbiology: A human perspective. $4^{\text {th }}$ edition. Mc Graw Hill. Pp. 610 $-628$.

Schlegel, H.G. (2002). General Microbiology. $7^{\text {th }}$ ed. Cambridge Low Price Edition. Cambridge University, Press. UK. Pp. $377-8$.

Shamsuddeen, U. and Ameh J.B. (2003). Survey on the possible critical control points during the production of Balangu in Kano. Bayero Journal of Pure and Applied Sciences 1(1): December, 2008. Page $76-79$.

Yakubu, A. (2009). The uses of Daddawa in Foods as a Condiment. "Personal Communication." 